\title{
Anaesthetic management of peripartum cardiomyopathy for emergency caesarean section: A case report
}

\section{Acil sezaryen operasyonunda peripartum kardiyomiyopatinin anestezi açısından yönetimi:Olgu sunumu}

\author{
Teena Bansal*, Sarla Hooda \\ Department of Anaesthesiology and Critical Care (T. Bansal, DA, DNB, S. Hooda, MD), \\ University of Health Sciences, Rohtak-124001 India
}

\begin{abstract}
Peripartum cardiomyopathy is a rare but life threatening condition. Anaesthetic management of a patient with peripartum cardiomyopathy for caesarean section is a major challenge for anaesthesiologist. Timely diagnosis of the condition, institution of appropriate medication regimen, a carefully chosen anaesthetic technique and vigilant perioperative monitoring are essential for optimizing outcome in these patients. The goals of anaesthetic management include maintenance of optimal ventricular preload and afterload while avoiding any anaesthesia induced myocardial depression.
\end{abstract}

Keywords: Peripartum cardiomyopathy, caesarean secion, anaesthetic management

\section{Özet}

Peripartum kardiyomyopati nadir ancak yaşamı tehdit eden bir durumdur. Peripartum kardiyomyopatisi olan bir hastanın sezaryen ameliyatı için anestezisinin yönetimi anestezist açısından önemli bir sorundur.Durumun vaktinde tanı alması, uygun tedavi rejiminin oluşturulması, dikkatlice seçilmiş anestezi tekniği ve dikkatli perioperatif monitorizasyon uygulanması bu hastaların tedavi sonuçlarının en iyi hale getirilmesi açısından önemlidir.Anestezi yönetiminin hedefleri optimal ventriküler preload ve afterload sağlarken anestezinin indüklediği herhangi bir myokardiyal depresyondan kaçınmaktır.

Anahtar sözcükler: Peripartum kardiyomiyopati, sezaryen, anestezi yönetimi

Geliş tarihi/Received: 29 July, 2013; Kabul tarihi/Accepted: 16 May, 2014

\section{*Corresponding author:}

Dr. Teena Bansal, Department of Anaesthesiology and Critical Care, University of Health Sciences, Rohtak-124001 India. E-mail: aggarwalteenu@ rediffmail.com

\section{Introduction}

Peripartum cardiomyopathy (PPCM) is a serious myocardial problem. In the final month of pregnancy, it can lead to cardiac failure if a left ventricular ejection fraction (LVEF) is $<45 \%$ without an identifiable cause of cardiac failure. The clinical presentation and the basic and intensive interventional strategies of the disease are more or less similar to that of dilated cardiomyopathy; however at al. points of time the pregnant or lactating state of mother and the subsequent effect of the medication and therapeutic interventions on the foetus or neonate need to be considered [1]. The goals of anaesthetic management include maintenance of optimal ventricular preload and afterload while avoiding any anaesthesia induced myocardial depression. A vigilant monitoring is essential throughout surgery and in the postoperative period to avoid complications [2]. 


\section{Case report}

A 24 year old female primigravida presented with complaint of dyspnea at 34 weeks of gestation. She reported regular antenatal checkups during the first and second trimesters with no history of preeclampsia or any other comorbid condition. She had no significant past history. On general physical examination, there was peripheral oedema without signs of heart failure like raised jugular venous pressure and hepatomegaly. Blood pressure (BP) was 112/64 mm Hg and pulse rate was 100/min with occasional missed beats. On systemic examination, heart sounds appeared normal with a pan systolic murmur in mitral area. Electrocardiography (ECG) showed non specific ST-T segment wave changes with occasional ectopic beats. Echocardiography revealed LVEF 38\%, left ventricular hypokinesia with mild to moderate mitral regurgitation suggesting PPCM. She was on tablet carvedilol $3.125 \mathrm{mg}$ and lasix $20 \mathrm{mg}$ as per advice of cardiologist. Elective caesarean section was planned at 37 weeks of gestation. However, she presented to the hospital at 36 weeks of gestation in labour with rupture of membranes. The obstetrician planned an urgent caesarean section in view of fetal distress.

Patient was reviewed for preanaesthetic check up. She had no fresh complaint. Airway assessment was unremarkable and spine was normal. Other investigations like hemoglobin, bleeding time, clotting time and urine examination were within normal limits. Spinal anaesthesia was planned for the procedure. The anaesthetic procedure was explained to the patient and high risk written and informed consent was obtained. In the operating room, monitors were attached including arterial oxygen saturation $\left(\mathrm{SpO}_{2}\right)$ and ECG. In addition monitoring of invasive blood pressure (IBP) and central venous pressure was started. Her baseline BP was $116 / 62 \mathrm{~mm} \mathrm{Hg}$ and pulse was $96 /$ min with occasional missed beats and $\mathrm{SpO}_{2}$ was $99 \%$. Spinal anaesthesia was given using $1.2 \mathrm{~mL}$ of $0.5 \%$ hyperbaric bupivacaine with $25 \mu \mathrm{g}$ fentanyl. Adequate sensory block was achieved upto $\mathrm{T}_{4}$ level.

After 10 minutes of delivery of baby, systolic BP dropped to $80 \mathrm{~mm} \mathrm{Hg}$. Ephedrine was given intravenously along with infusion of dopamine. BP rose to $110 / 70 \mathrm{~mm} \mathrm{Hg}$. Surgery lasted for 45 minutes. Postoperative BP was 110/70 mm Hg and pulse was 98/min. The patient was monitored in the intensive care unit postoperatively and shifted back to ward on 3rd postoperative day. She was discharged on the 10th postoperative day in stable condition. The patient was followed up in the obstetric and cardiovascular surgery outpatient departments and at 6 months after surgery she was in good condition without any complaint.

\section{Discussion}

PPCM is a serious myocardial problem. Anaesthetic management of patients of PPCM with reduced systolic function is challenging and may be associated with high mortality. Two key factors exist in the management of patients with cardiomyopathy: One is to improve systolic function and the other is to prevent sudden death due to ventricular arrhythmias. To improve systolic function, patient should initially be managed medically with administration of diuretics, beta blockers, angiotensin converting enzyme (ACE) inhibitors or angiotensin receptor blockers [3]. Our patient was being managed with diuretics and beta blocker. Biventricular pacing, cardioplasty or cardiac transplant may also be required to improve cardiac function [4]. Biventricular pacing and cardioplasty is beneficial for patients with severe cardiomyopathy in moderate to severe congestive heart failure with ejection fraction $<30 \%$.

The preoperative preparation of these patients must be meticulous as they have minimal or no cardiac reserves. Echocardiography needs to be done in all the patients suspected with PPCM to clinch the diagnosis. Presence of left ventricle clot should also be ruled out by echocardiography. Anticoagulants is recommended in patients with PPCM, especially if the ejection fraction is less than $35 \%$ and there are other associated risk factors such as severely dilated ventricles, atrial fibrillation and presence of mural thrombus on 
echocardiography or history suggestive of previous thrombolic episodes [1].

1. Goals of anaesthetic management are [3]

2. Myocardial depression should be avoided.

3. Normovolemia should be maintained.

4. Avoid overdose of drugs during induction as the circulation time is slow.

5. Ventricular afterload should be avoided.

6. Avoid sudden hypotension when regional anaesthesia is the choice.

Anaesthetic management for caesarean section in women in PPCM should incorporate measures to optimally reduce preload and afterload while maintaining an increase in myocardial contractility. Correct choice of anaesthesia and precise titration is crucial for a favorable outcome. There are reports of anaesthetic management techniques that include general anaesthesia with inhalational agents, epidural anaesthesia, spinal anaesthesia, combined spinal epidural anaesthesia and anaesthesia with continuous spinal catheter [59].

The choice of anaesthetic technique has to be individualized based on patients' symptoms and urgency for caesarean. General anaesthesia is preferred mainly in emergency situation and in hemodynamically unstable patients with decompensated heart failure. Though its advantage is rapid induction of anaesthesia but it causes mild to severe myocardial depression [10]. In addition, it carries a high risk because these patients may develop congestive heart failure or arrhythmias during intraoperative period. Regional anaesthesia is the most preferred choice in undecompensated patients. So we used regional anaesthesia. Regional anaesthesia provides many advantages for patients with PPCM as it avoids the stress of general anaesthesia. In addition sympathetic blockade associated with regional anaesthesia is beneficial in a decompensated heart as it decreases both preload and afterload [1]. Though advantage of epidural anaesthesia is hemodynamic stability during the surgery but as the patient was in active labour and epidural anaesthesia takes longer for the anaesthesia to occur, so considering the emergency of the situation, we decided to use spinal anaesthesia.

Though use of a spinal catheter in continuous spinal anaesthesia technique (CSA) offers several advantages over single shot spinal anaesthesia like fewer hemodynamic alterations and side effects by enabling the reduction $\&$ fractionation of the induction dose through a catheter. But the major disadvantage after a dural puncture with an epidural needle is that post dural puncture headache can occur [9]. So we avoided CSA \& decided to use single shot spinal anaesthesia using low dose bupivacaine with fentanyl.

Fall in blood pressure was corrected with injection ephedrine and infusion of dopamine. Over hydration may not be desirable as it may lead to congestive heart failure. Fluid management is critical. Therefore a vasopressor to mitigate against the vasodilating effect of the anaesthetics is a rational approach as we used ephedrine and dopamine in our case.

A vigilant monitoring is essential throughout the surgery and in the postoperative period to avoid complications like arrhythmias, hypotension, hypoxemia, pulmonary oedema, electrolyte disturbances, myocardial ischemia, thromboembolism and even sudden death. In the course of the disease, cardiac function recovers in around half of the women with PPCM, but in those with persistent left ventricular dysfunction even after 6-12 months, a mortality of upto $85 \%$ has been reported, indicating irreversibility and is an absolute contraindication for future pregnancies. Those with documented poor recovery might be considered for cardiac transplants [2].

To conclude, PPCM is a serious myocardial problem. A vigilant monitoring is essential throughout surgery and in the post operative period to avoid complications. 


\section{References}

1. Ramachandran R, Rewari V, Trikha A. Anaesthetic management of patients with peripartum cardiomyopathy. J Obstet Anaesth Crit Care 2011; 1: 5-12.

2. Soni B, Gautam PL, Grewal A, Kaur H. Anaesthetic management of two cases of peripartum cardiomyopathy. J Obstet Anaesth Crit Care 2011; 1: 41-5.

3. Bansal T, Hooda S. Anaesthetic management of an elderly patient with dilated cardiomyopathy undergoing surgery for fracture of trochanter. Webmed Central Anaesthesia 2011; 2: WMC002567.

4. Nocoletti I, Tomei R, Zanotto G, Vecchia ED, Zorzi E, Vassanelli C. The beneficial effect of biventricular pacing on ventricular tachycardia in a patient with non ischemic cardiomyopathy. International Journal of Cardiology 2008; 126: 29-31.

5. Kaufman I, Bondy R, Benjamin A. Peripartum cardiomyopathy and thromboembolism; anesthetic management and clinical course of an obese, diabetic patient. Can J Anaesth 2003; 50: 161-5.

6. Peng TC, Chuah EC. Peripartum cardiomyopathy- a case report. Acta Anaesthesiol Sin 2001; 39: 47-51.

7. Domenech AP, Hernandez- Palazon J, Tortosa SJA, Burguillos LS, Alonso MB. Puerperal cardiomyopathy and pulmonary edema after caesarean section. Rev Esp Anestesiol Reanim 2002; 49: 156-9.

8. Shnaider R, Ezri T, Szmuk P, Larson S, Warters RD, Katz J. Combined spinalepidural anesthesia for cesarean section in a patient with peripartum dilated cardiomyopathy. Can J Anaesth 2001; 48: 681-3.

9. Velickovic IA, Leicht CH. Continuous spinal anaesthesia for cesarean section in a parturient with severe recurrent peripartum cardiomyopathy. Int J Obstet Anesth 2004; 13: 40-3.

10. Mcindoe AK, Hammond EJ, Babington PC. Peripartum cardiomyopathy presenting as cardiac arrest at induction of anaesthesia for emergency caesarean section. Br J Anaesth 1995; 75: 97-101. 